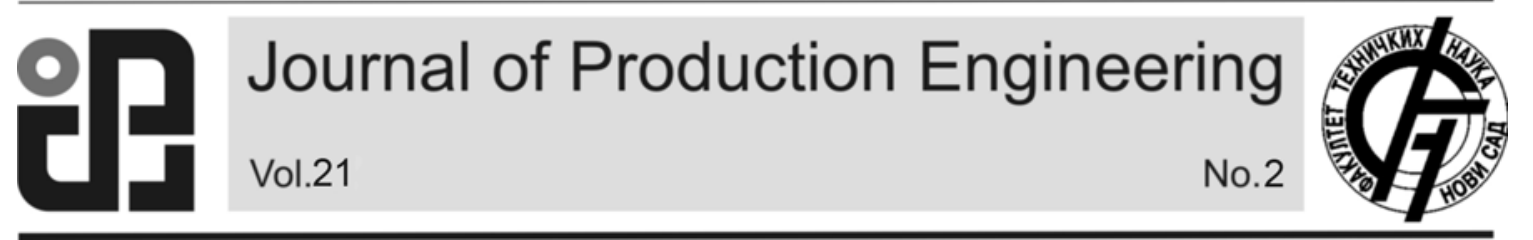

JPE (2018) Vol.21 (2)

Janković, V., Jović, S., Đokić, J.

Preliminary Note

\title{
MANAGEMENT OF TOTAL ENTREPRENEURIAL ACTIVITY BY ADAPTIVE NEURO-FUZZY TECHNIQUE
}

Received: 21 September 2018 / Accepted: 10 November 2018

\begin{abstract}
Adaptive neuro fuzzy network or ANFIS could be used for different aspects of prediction during productive development. In this study ANFIS network was appliced for prediction of bending and thickness of shaped surface by laser formation. Laser manufacturing represent imporant part in new productive development. Shaped surface modeling by laser forming process needs many irradiations along surface paths with different parameters of heating. This surface requires thickening and bending in order to get required shapes. In this study was attempted to analyze the process parameters influence on the bending and thickening of the shaped surface by laser. The used inputs were circular and radial laser scan, laser spot diameter, laser power and scan speed. The selection procedure can produce results to simplify the shaped surface forming. Finally it was attamted to determine how services as added values have infleunce on the enterpreneusthip activity for laser manufacturing business.
\end{abstract}

Key words: ANFIS; forecasting; laser manufacturing; entrepreneurial activity; business

Upravljanje totalnom preduzentičkom aktivnošću primenom adaptivne neuro-fazi logike. Adaptivna neuro fazi mreža ili ANFIS se može koristiti u različitim aspektima predikcije u toku razvoja poroizvodnje. U ovom radu je ANFIS mreža korišćena za predikciju savijanja i debljine površine primenom lasera. Primena lasera u proizvodnji predstavlja jedan od najvažnijih delova u proizvodnji. Modelovanje oblikovanih površina primenom laserske tehnologije zahteva mnoga lasetska zračenja duž putanja površine sa različitim parametrima zagrevanja. Glavni parametri kod oblikovanja neke površine su savijanje i debljina te povšina nakon oblikovanja kako bi se dobili traženi oblici. U ovom radu je analiziran proces uticaja pojedinih parametara na savijanje i debljinu oblikovane površine primenom laserske tehnologije. Korišćeni ulazi su radijalno i cirkulanro lasersko skeniranje, prečnik laserke dodirne tačke sa površinom, snaga lasera i brzina skeniranja laserom. Procedura selekcija može da da rezultate kako bi formiranje oblikovanoh površina bilo uprošćeno. Na kraju je urađena analiza kako dodatne usluge mogu da utiči na preduzetničku aktivnost primenom laserske proizvodnje.

Ključne reči: ANFIS; predikcija; proizovdnja laserom; preduzetnička aktivnost; biznis.

\section{INTRODUCTION}

Shaped surface modeling by lasers requires surface deformation often because of thermal stresses produced by controlled laser beams, which scan surface. Complex shaped surface could be modeled from flat surfaces by the numerous laser scans along different directions (radial and circular for example) and with suitable machining parameters. Definition of the machining parameters could be very challenging and complex task due to the high nonlinearities of the shaped surface modeling. There were many experimental, numerical and empirical methods for shaped surface modeling by laser forming process.

In article [1] was used spiral irradiating scheme for laser forming of a saddle shape and it as proved that this irradiating scheme was suitable for modeling of saddle shapes. With increasing of the number of irradiation passes, curvatures of saddle shape were increased considerably [2]. Despite a lot of research was done in the field of laser forming, generation of a threedimensional surface by this process is still a challenging task. Effect of spot diameter variation for the laser forming process was analyzed in study [3]. In article [4] was found that the combination of radial and circular scan schemes works better for achieving higher bending angle of the obtained surface. Due to the high peak temperature and heating rate caused by the latter shaped beam, a higher value of micro hardness in the transformation hardened zone was found in article [5]. In work [6], two different irradiating schemes were used and compared for flame forming of a bowl-shaped surface and it was proved that the obtained bowl-shaped surface with spiral irradiating scheme has larger curvatures and symmetry and lower residual stresses in comparison with the obtained bowl-shaped surface with combined irradiating scheme. To improve the forming quality of parts fabricated by laser direct metal forming, the forming process of three-dimensional parts under open-loop LDMF system was studied in paper [7] and it was suggested that uneven surface of parts was caused by instability of process parameters. Laser forming is a thermal forming process, which uses laser beam irradiation to produce desired final forms. With increasing laser power, line energy, and heat flux, dome height increases and with increasing beam diameter, sheet thickness, and scan velocity, dome height decreases notably [8]. Due to an enhancement of ductility of the surface region, higher compressive residual stresses can be achieved for the adapted process chains after the final peening step [9]. The laser forming process, in which a bending deformation of a metal 
plate is produced by non-uniform thermal stress coming from nonlinear laser-heating cycles, is a promising technology for the rapid production of metallic shaping components [10]. Laser forming continues to be a promising technology in manufacturing due to its fast speed, flexibility, and low-cost [11, 12]. In laser forming of three-dimensional surfaces, simultaneous bending and thickening of the sheet being formed are often required [13, 14].

The main goal in this study was to avoid high nonlinearity of the mathematical approaches by using soft computing methodology. Soft computing methods do not require knowledge of internal system and these methods can provide compact solution for multivariable problems. Adaptive neuro-fuzzy inference system (ANFIS) [15] was used to determine the most dominant machining factors for the shaped surface modeling process by laser forming process. Finally in the article was determined influence of services as benefits on the entrepreneurship business on the laser manufacturing process.

\section{METHODOLOGY}

\subsection{Laser manufacturing process of shaped surface}

$\mathrm{Yb}$ fiber laser was used for the shaped surface modeling process. Stainless steel sheet AISI 304 was used as working specimens. Diameter of the collimated laser beam was $15 \mathrm{~mm}$, which could produce diameter of spot of $250 \mu \mathrm{m}$ by the optical system. Laser displacement sensor was used for deformation measurement of the bending and thickening of the shaped surface.

Radial and circular laser scans were performed for the laser irradiation since this combination of the laser scan was the most suitable for the complex surface forming. Four machining parameters were considered as inputs for the shaped surface modeling process. Circular laser scan was produced bending of the shaped surface and radial laser scan produced thickening of the shaped surface. These input parameters are presented in Table 1 for the bending prediction of the shaped surface. Table 2 shows the inputs for the thickening prediction of the shaped surface. Bending and thickening of the shaped surface were used as output factors. The main aim was to analyze the influence of the input factors on the bending and thickening variations of the shaped surface.

\begin{tabular}{|l|l|l|l|}
\hline Inputs & Parameters & Min. & Max. \\
\hline Input 1 & Circular scan radius [mm] & 30 & 50 \\
\hline Input 2 & Laser spot diameter [mm] & 2 & 5 \\
\hline Input 3 & Laser power [W] & 250 & 750 \\
\hline Input 4 & Laser scan speed [m/min] & 0.5 & 7 \\
\hline
\end{tabular}

Table 1. Used parameters for bending of shaped surface

\begin{tabular}{|l|l|l|l|}
\hline Inputs & Parameters & Min. & Max. \\
\hline Input 1 & Radial scan lines [mm] & 20 & 40 \\
\hline Input 2 & Laser spot diameter [mm] & 2 & 5 \\
\hline Input 3 & Laser power [W] & 250 & 750 \\
\hline Input 4 & Laser scan speed [m/min] & 0.5 & 7 \\
\hline
\end{tabular}

Table 2. Used parameters for thickness of shaped surface

\subsection{Laser manufacturing business}

Entrepreneurship is a multilevel and complex phenomenon that gained importance in the global economy because of changes in employee qualifications, work contents, and psychological contracts in the employment field. Entrepreneurship contributes to economic growth in being a conveyor of new or existing knowledge spillover and creative ideas that might otherwise not be utilized and realized for the benefit of all. Linking entrepreneurship to economic growth means linking the individual level to the aggregate levels. The most significant contribution of small businesses and entrepreneurial activity is their ability to innovate.

Various studies show that entrepreneurs contribute to economic development, job creation, and different aspects of wellbeing through creative destruction [16]. The most popular themes in entrepreneurship research have traditionally revolved around micro-level factors including opportunity recognition, motivation, financing and performance. Opportunity identification is considered a mainstream fundamental issue in entrepreneurship research, given that it is an important entrepreneurial capability and a source of competitive advantage.

Table 3 shows the input and output parameters, which are used in this study for, laser manufacturing business. Services include value added in wholesale and retail trade, transport, and government, financial, professional, and personal services such as education, health care, and real estate services. Also included are imputed bank service charges, import duties, and any statistical discrepancies noted by national compilers as well as discrepancies arising from rescaling. Value added is the net output of a sector after adding up all outputs and subtracting intermediate inputs. It is calculated without making deductions for depreciation of fabricated assets or depletion and degradation of natural resources. Unemployment refers to the share of the labor force that is without work but available for and seeking employment. GNI per capita (formerly GNP per capita) is the gross national income. GNI is the sum of value added by all resident producers plus any product taxes (less subsidies) not included in the valuation of output plus net receipts of primary income (compensation of employees and property income) from abroad.

\begin{tabular}{|c|c|}
\hline \multirow[t]{3}{*}{ Inputs } & 1. GNI per capita \\
\hline & 2. Services, etc., value added ( $\%$ of GDP) \\
\hline & $\begin{array}{l}\text { 3. Unemployment, (\% of female labour } \\
\text { force) }\end{array}$ \\
\hline Output & 1. Total entrepreneurial activity (\%) \\
\hline
\end{tabular}

Table 3. Used parameters in study for laser manufacturing business

\subsection{ANFIS methodology}

MATLAB software is employed for whole procedure of ANFIS training and testing. During training process, ANFIS parameters are identified optimized.

In the training process the hybrid learning algorithms were applied. The hybrid algorothm is 
coupled of least squares estimation and the gradient decline order.

To assess the ANFIS success RMSE statistical indicator was used. The indicator could be presented as follows:

$$
R M S E=\sqrt{\frac{\sum_{i=1}^{n}\left(P_{i}-O_{i}\right)^{2}}{n}},
$$

where $P_{i}$ and $O_{i}$ are known as the experimental and forecast values, respectively, and $n$ is the total number of data samples.

\section{RESULTS}

\subsection{Laser manufacturing of shaped surface}

ANFIS network was used for find the parameters influence on the output variables (bending of shaped surface). The parameter with smaller RMSE has more influence on the output parameters. The following results are achieved:

\section{Circular scan radius, $\mathbf{R M S E}=\mathbf{1 . 7 0 7 1}$}

2. Laser spot diameter, $\mathrm{RMSE}=2.0818$

3. Laser power, $\mathrm{RMSE}=2.3494$

4. Laser scan speed, $\mathrm{RMSE}=2.3779$

According the results the input parameter 1 (Circular scan radius) has the highest influence on the bending of shaped surface since the input 1 has the smallest RMSE.

ANFIS network was used for find the parameters influence on the output variables (thickness of shaped surface). The parameter with smaller RMSE has more influence on the output parameters. The following results are achieved
1. Radial scan lines, $\mathrm{RMSE}=7.5269$

2. Laser spot diameter, $\mathrm{RMSE}=\mathbf{6 . 7 0 8 2}$

3. Laser power, $\mathrm{RMSE}=6.9218$

4. $\quad$ Laser scan speed, $\mathrm{RMSE}=7.5202$

According the results the input parameter 2 (Laser spot diameter) has the highest influence on the thickness of shaped surface since the input 2 has the smallest RMSE.

\subsection{Laser manufacturing business}

ANFIS network was used for find the parameters influence on the output variables (total entrepreneurial activity of the laser manufacturing business). The parameter with smaller RMSE has more influence on the output parameters. According the Table 4 the input parameter 2 (services) has the highest influence on the total entrepreneurial activity since the input 2 has the smallest RMSE.

Table 5 shows the numerical results for the two parameters influence on the total entrepreneurial activity. GNI per capita and services forms the optimal combination which is the most influential on the total entrepreneurial activity prediction.

\section{Total entrepreneurial activity}

GNI per capita $-->$ RMSE $=4.9919$

Services, etc., value added $->$ RMSE $=4.2391$

Unemployment, --> RMSE $=5.7961$

Table 4. Forecasting of the total entrepreneurial activity of laser manufacturing business according to single parameters

$$
\begin{aligned}
& \text { Total entrepreneurial activity } \\
& \hline \text { GNI per capita-Services, etc., value added --> RMSE }=\mathbf{3 . 3 8 7 4} \\
& \text { GNI per capita-Unemployment, --> RMSE }=4.5238 \\
& \text { Services, etc., value added- Unemployment, --> RMSE }=3.6392 \\
& \text { Table 5. Forecasting of the total entrepreneurial activity of laser } \\
& \text { manufacturing business according to two parameters }
\end{aligned}
$$

\section{CONCLUSION}

Shaped surface modeling by laser forming process is a complex task due to the many processing parameters. Therefore in this study was applied a soft computing methodology to overcome the prediction difficulties of the bending and thickening prediction of the shaped surface by removing some unnecessary input parameters. Finally it was attamted to determine how services as added values have infleunce on the enterpreneusthip activity for laser manufacturing business.

\section{REFERENCES}

[1] Safari, M., \& Farzin, M. Experimental investigation of laser forming of a saddle shape with spiral irradiating scheme. Optics \& Laser Technology, 66, (2015) 146-150.

[2] Safari, M., Farzin, M., \& Yazdi, P. Experimental and numerical investigation of spiral irradiating scheme for flame forming of a bowl shaped surface. International Journal of Material Forming, 8(1), (2015) 99-109.

[3] Chakraborty, S. S., More, H., \& Nath, A. K. Laser 
forming of a bowl shaped surface with a stationary laser beam. Optics and Lasers in Engineering, 77, (2016) 126-136.

[4] Chakraborty, S. S., Racherla, V., \& Nath, A. K. Parametric study on bending and thickening in laser forming of a bowl shaped surface. Optics and Lasers in Engineering, 50(11), (2012) 1548-1558.

[5] Sun, P., Li, S., Yu, G., He, X., Zheng, C., \& Ning, $\mathrm{W}$. Laser surface hardening of $42 \mathrm{CrMo}$ cast steel for obtaining a wide and uniform hardened layer by shaped beams. The International Journal of Advanced Manufacturing Technology,70(5-8), (2014) 787-796.

[6] Safari, M., \& Farzin, M. A comparative study on two different irradiating schemes for flame forming of a bowl-shaped surface. The International Journal of Advanced Manufacturing Technology, 80(1-4), (2015) 199-207.

[7] Pi, G., Zhang, A., Zhu, G., Li, D., \& Lu, B. Research on the forming process of threedimensional metal parts fabricated by laser direct metal forming. The International Journal of Advanced Manufacturing Technology, 57(9-12), (2011) 841-847.

[8] Shahabad, S. I., Naeini, H. M., Roohi, A. H., Soltanpour, M., \& Tavakoli, A. Height prediction of dome-shaped products in laser forming process. The International Journal of Advanced Manufacturing Technology, 88(5-8), (2017) $2227-$ 2236.

[9] Andreas, K., Henneberg, J., Koch, J., \& Merklein, M. Local adjustment of surface integrity of forming tools by adaptation of tool making process. Procedia CIRP, 45, (2016) 339-342.

[10] Shi, Y., Zhang, C., Sun, G., \& Li, C. Study on reducing edge effects by using assistant force in laser forming. Journal of Materials Processing
Technology, 227, (2016) 169-177.

[11] Ding, Y., Zhang, X., \& Kovacevic, R. A laserbased machine vision measurement system for laser forming. Measurement, 82, (2016) 345-354.

[12] Gill, A. S., Telang, A., \& Vasudevan, V. K. Characteristics of surface layers formed on inconel 718 by laser shock peening with and without a protective coating. Journal of Materials Processing Technology, 225, (2015) 463-472.

[13] Chakraborty, S. S., Maji, K., Racherla, V., \& Nath, A. K. Investigation on laser forming of stainless steel sheets under coupling mechanism. Optics \& Laser Technology, 71, (2015) 29-44.

[14] Safari, M. A study on flame forming of bowl shaped surface with various spiral irradiating schemes. Acta Mechanica Solida Sinica, 29(3), (2016) 328-336.

[15] Jang, J.-S.R, ANFIS: Adaptive-Network-based Fuzzy Inference Systems, IEEE Trans. On Systems, Man, and Cybernetics (1993), Vol.23, 665-685.

[16] Seuneke, P., Bock, B.B., Exploring the roles of women in the development of multifunctional entrepreneurship on family farms: an entrepreneurial learning approach. NJAS Wageningen Journal of Life Sciences 74-75 (2015) 41-50.

Authors: Srđaj Jović, Jelena Đokić, University of Priština, Faculty of Technical Sciences in Kosovska Mitrovica, Kneza Milosa 7, 38220 Kosovska Mitrovica, Serbia.

Vučina Janković, Opština Zvečan, Kralja Milutina b.b. 38227 Zvečan, Serbia.

E-mail: vucina.jankovic1111@yahoo.com srdjanjovic2016@hotmail.com djokicjelenaftn@yahoo.com 